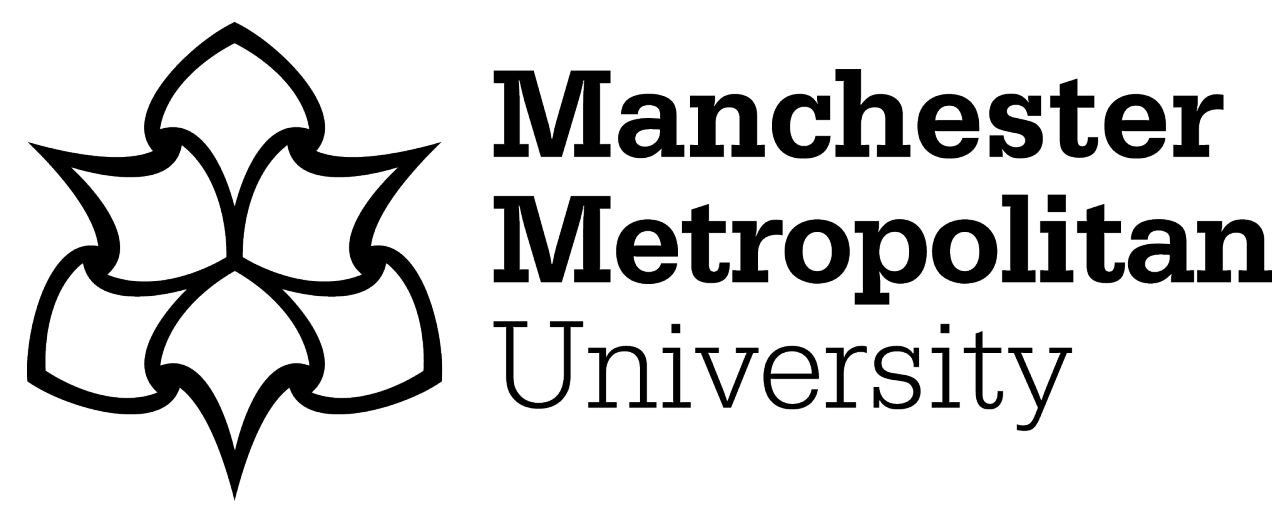

de Oliveira, Andrea, Polezer, Gabriela, Godoi, Ricardo HM, Vermaak, Sanja Potgieter, de Souza, Rodrigo AF, Andreoli, Rita V and Yamamoto, Carlos I (2020) EXPRESS: Atomic Absorption Spectrometry Methods to Access the Metal Solubility of Aerosols in Artificial Lung Fluid. Applied Spectroscopy, 74 (8). pp. 932-939. ISSN 0003-7028

Downloaded from: https: //e-space.mmu.ac.uk/625133/

Version: Accepted Version

Publisher: SAGE Publications

DOI: https://doi.org/10.1177/0003702820906422

Please cite the published version 


\title{
Atomic Absorption Spectrometry Methods to Access the Metal Solubility of Aerosols in Artificial Lung Fluid
}

\author{
Gabriela Polezer ${ }^{a}$, Ricardo H. M. Godoi ${ }^{a}$, Sanja Potgieter-Vermaak ${ }^{b}$, Rodrigo A. F. de Souza, \\ Rita V. Andreolic, Carlos I. Yamamoto ${ }^{\mathrm{d}}$, Andrea Oliveira* ${ }^{*}$ e \\ a Environmental Engineering Department, Federal University of Paraná, Curitiba, PR, Brazil; \\ ${ }^{\mathrm{b}}$ Ecology and Environment Research Centre, Department of Natural Sciences, Manchester \\ Metropolitan University, Manchester M1 5GD, UK; \\ c State University of Amazonas, Meteorology Department, Manaus, Brazil; \\ ${ }^{\mathrm{d}}$ Chemical Engineering Department, Federal University of Paraná, Curitiba, PR, Brazil; \\ ${ }^{\text {e }}$ Chemistry Department, Federal University of Paraná, Curitiba, PR, Brazil.
}

\begin{abstract}
Recent studies to quantify the health risks that fine particulate matter with an aerodynamic less than 2.5 micrometers $\left(\mathrm{PM}_{2.5}\right)$ pose use in vitro approaches. One of these approaches is to incubate $\mathrm{PM}_{2.5}$ in artificial lysosomal fluid for a given period at body temperature. These body fluids used have a high ionic strength and as such can be challenging samples to analyze with atomic spectroscopy techniques. As $\mathrm{PM}_{2.5}$ is a primary health hazard because it is tiny enough to penetrate deep into the lungs and could, in addition, dissolve in the lung fluid it is important to quantify elements of toxic and/or carcinogenic concerns, reliably and accurately. Sophisticated instrumentation and expensive pre-treatment of challenging samples are not always available, especially in developing countries. To evaluate the applicability of GFAAS without Zeeman correction capability to detect trace quantities of heavy metals leached from $\mathrm{PM}_{2.5}$ on to artificial lung fluid, uni- and multivariate approaches have been used for optimization purposes.
\end{abstract}

The limits of quantification, LOQ, obtained by the optimized method were: $2 \mu \mathrm{g} \mathrm{L}^{-1}(\mathrm{Cu}), 3$ $\mu \mathrm{g} \mathrm{L} \mathrm{L}^{-1}(\mathrm{Cr}), 1 \mu \mathrm{g} \mathrm{L}^{-1}(\mathrm{Mn})$ and $10 \mu \mathrm{g} \mathrm{L}^{-1}(\mathrm{~Pb})$. The addition/recovery experiments had a mean accuracy of: $(\mathrm{Cu}) 99 \pm 7 \% ; 110 \pm 8 \%(\mathrm{Cr}) ; 95 \pm 9 \%(\mathrm{Mn})$ and $96 \pm 11 \%(\mathrm{~Pb})$. The average soluble fractions of $\mathrm{PM}_{2.5}$ incubated in artificial lysosomal fluid (ALF) for 1 hour were: $1.2 \pm 0.01 \mathrm{ng} \mathrm{m}^{-3}$ $\mathrm{Cu}, 0.4 \pm 0.01 \mathrm{ng} \mathrm{m}^{-3} \mathrm{Cr}, 0.6 \pm 0.01 \mathrm{ng} \mathrm{m}^{-3} \mathrm{Mn}$ and $4.8 \pm 0.03 \mathrm{ng} \mathrm{m}^{-3} \mathrm{~Pb}$. Using historical elemental 
averages of $\mathrm{PM}_{2.5}$ in Curitiba ( $\mathrm{Cu} 3.3 \mathrm{ng} \mathrm{m}^{-3}, \mathrm{Cr} 2.1 \mathrm{ng} \mathrm{m}^{-3}, \mathrm{Mn} 6.1 \mathrm{ng} \mathrm{m}^{-3}, \mathrm{~Pb} 21 \mathrm{ng} \mathrm{m}^{-3}$ ), the percentage bioaccessibility were determined to be $\mathrm{Cu} 38 \%$; $\mathrm{Cr} 20 \%$; $\mathrm{Mn} \mathrm{10 \%}$; and $\mathrm{Pb} 23 \%$. The elemental values of the atmospheric soluble fraction of $\mathrm{Cu}, \mathrm{Cr}$ and, $\mathrm{Mn}$ were below the inhalation risk concentrations. However, for $\mathrm{Pb}$, the atmospheric soluble fraction exceeded the inhalation unit risk of $0.012 \mathrm{ng} \mathrm{m}^{-3}$.

This robust and straightforward GF AAS method is pivotal for low and middle-income countries were most air pollution adverse effects occur and established lower-cost technologies are likely unavailable.

Keywords: $\mathrm{PM}_{2.5}$, bioaccessibility, artificial lysosomal fluid, inorganic elements, GFAAS.

*Corresponding author: Andrea Oliveira Tel: +55 (41) 3361-3182

e-mail address: aoliveira@quimica.ufpr.br 


\section{Introduction}

Aerosol particles comprise organic and inorganic components, some of which could be considered toxic and/or carcinogenic ${ }^{1-8}$ leading to diverse health effects, including cardiovascular, pulmonary diseases and of late, stroke. ${ }^{9}$ These effects are related to particle size and composition of particulate matter, ${ }^{10}$ as the inhaled $\mathrm{PM}_{2.5}$ can reach the gas exchange region of the alveoli in the lungs upon inhalation exposure. The chemical composition, especially pertaining to the toxic and carcinogenic components, plays a significant part in the risk upon exposure due to its potential mobility in lung fluid (causing a bioaccessible fraction). While the evidence for the differential toxicity of particulate matter is far from conclusive, the nature and action of chemical elements are estimated by their acute inhalation reference concentration ( $\mathrm{RfC})$, which is widely published by health and environmental agencies. The inorganic contaminants selected here constitute an important class of pollutants which have received the attention of researchers all over the world, mainly due to their harmful effects on living beings. The RfCs of the elements discussed in this paper are: $\mathrm{Cu}=100 \mu \mathrm{g} \mathrm{m}^{-3} ;{ }^{11} \mathrm{Cr}(\mathrm{VI})=8 \mathrm{ng} \mathrm{m}^{-3} ;{ }^{12} \mathrm{Mn}=50 \mathrm{ng} \mathrm{m}^{-3} ;{ }^{13}$ and $\mathrm{Pb}=0.012 \mathrm{ng} \mathrm{m}^{-3} .{ }^{14}$

Due to solubilized particulate matter's potential adverse health effects, in vitro studies report on the bioaccessibility of $\mathrm{PM}_{2.5}$ in artificial lysosomal fluid (ALF). ${ }^{15,16}$ However, as biological fluids produce a complex matrix for analysis, with for example a high salt content ${ }^{17}$ it becomes a challenge for the analyst, especially in laboratories where analytical equipment has limitations. In studies involving the bioaccessibility of inorganic elements in ALF, these elements were determined by inductively coupled plasma mass spectrometry and optical emission spectrometry (ICP-MS and ICPOES), during which the ionic strength has to be carefully managed by either sever sample dilution or removal of the ionic species by pre-treatment. ${ }^{18-25}$ It is also possible to use graphite furnace atomic absorption spectrometry (GFAAS) for the analysis of trace quantities of elements, however, high salt content will also interfere with the analysis, as well as cause high backgrounds. The latter may be addressed with the use of Zeeman Effect background corrector, ${ }^{11}$, 
26-27 but remains a problem if the instrument available does not have the Zeeman correction capability.

It is evident that although validated methods for the determination of the metals of interest in this matrix have been published, a robust, precise and accurate method with little or no sample preparation would be beneficial. This paper describes the development, optimization and validation of a method for the quantification of $\mathrm{Cu}, \mathrm{Cr}, \mathrm{Mn}$, and $\mathrm{Pb}$ in a high ionic strength matrix, using GFAAS, without Zeeman correction capabilities.

\section{Materials and Methods}

\section{Instrumentation}

All quantification measurements of $\mathrm{Cu}, \mathrm{Cr}, \mathrm{Mn}$ and $\mathrm{Pb}$ present in the ALF were carried out using a GFAAS (AA 6800, Shimadzu, Japan) equipped with a background correction by deuterium lamp, using pyrolytic graphite tubes longitudinally heated. Argon ( $99.9 \%$ pure) was employed as purge and protective gas. All analyses were performed employing $20 \mu \mathrm{L}$ of the sample and/or standard and reference solutions and $5 \mu \mathrm{L}$ of chemical modifier. The wavelengths used for $\mathrm{Cu}$ (324.8 nm), Cr $(360.5 \mathrm{~nm}), \mathrm{Mn}(279.5 \mathrm{~nm})$, and $\mathrm{Pb}(283.3 \mathrm{~nm})$, respectively. The analyte signal acquisition mode was obtained by area peak in agreement to the concentration level of the analyte.

\section{Reagents and Solutions}

Prior to analysis, all glass and plastic recipients were immersed in a $10 \%\left(\mathrm{v} \mathrm{v}^{-1}\right) \mathrm{HNO}_{3}$ solution for $24 \mathrm{~h}$ followed by rinsing with ultrapure water (resistivity higher than $18.2 \mathrm{M} \Omega \mathrm{cm}$ ). All solutions were prepared with $\mathrm{HNO}_{3}$ previously distilled in a quartz sub-boiling system (Distillacid, Berghof). The aqueous standard solutions employed were prepared using $1000 \mathrm{mg} \mathrm{L}^{-1}$ of each element $\mathrm{Cu}, \mathrm{Cr}, \mathrm{Mn}$ and $\mathrm{Pb}(\mathrm{SpecSol})$ in $1 \%\left(\mathrm{v} \mathrm{v}^{-1}\right) \quad \mathrm{HNO}_{3}$ solution. Stock solutions of each chemical modifier used, $\mathrm{Pd}\left(\mathrm{NO}_{3}\right)_{2}$ and $\mathrm{Mg}\left(\mathrm{NO}_{3}\right)_{2}$, were prepared by dissolving $0.6259 \mathrm{~g}$ of 
$\mathrm{Pd}\left(\mathrm{NO}_{3}\right)_{2} .2 \mathrm{H}_{2} \mathrm{O}$ (Sigma-Aldrich), and $2.6709 \mathrm{~g}$ of $\mathrm{Mg}\left(\mathrm{NO}_{3}\right)_{2} .6 \mathrm{H}_{2} \mathrm{O}$ (Sigma-Aldrich, in a $25 \mathrm{~mL}$ $1 \%\left(\mathrm{v} \mathrm{v}^{-1}\right) \mathrm{HNO}_{3}$ solution.

The ALF composition is the closest to human pulmonary environments, simulating the acidic cellular conditions under the phagocytosis process and it was prepared as described by Colombo et al. ${ }^{18}$ (Table S1).

In the experiments of the GFAAS instrumental conditions optimization, the recovery parameter was evaluated, being obtained by the ratio of the signal from ALF samples previously spiked with the analyte and the signal from the standard analyte solution (reference solution), both in the same concentration level. In these experiments, the final volume of ALF employed was about $5 \mathrm{~mL}$.

\section{Instrumental Parameters}

The general instrumental conditions that were optimized for the analysis of the four elements by GFAAS are show in Table I. For that purpose spiked ALF samples and standard solutions were used.

Table I. General heating program for the direct determination of $\mathrm{Cu}, \mathrm{Cr}, \mathrm{Mn}$ and $\mathrm{Pb}$ in $\mathrm{ALF}$ samples by GFAAS.

\begin{tabular}{lcccc}
\hline \multicolumn{1}{c}{ Step } & $\begin{array}{c}\text { Temperature } \\
\left({ }^{\circ} \mathbf{C}\right)\end{array}$ & $\begin{array}{c}\text { Ramp Time } \\
(\mathbf{s})\end{array}$ & $\begin{array}{c}\text { Hold Time } \\
(\mathbf{s})\end{array}$ & $\begin{array}{c}\text { Gas flow rate } \\
\left(\mathbf{L ~ m i n}^{-1}\right)\end{array}$ \\
\hline Drying 1 & 85 & 5 & 0 & 0.1 \\
Drying 2 & 110 & 50 & 0 & 0.1 \\
Pyrolysis 1 & $\mathrm{T}_{\text {pyr }}$ & 10 & 10 & 1 \\
Pyrolysis 2 & $\mathrm{T}_{\text {pyr }}$ & 0 & 3 & 0 \\
Atomization & $\mathrm{T}_{\text {atom }}$ & 0 & 3 & 0 \\
Clean & 2500 & 0 & 2 & 1 \\
\hline
\end{tabular}




\section{Determination of $\mathrm{Cu}, \mathrm{Cr}, \mathrm{Mn}$ and $\mathrm{Pb}$ in the $\mathrm{PM}_{2.5} A L F$-soluble fraction}

$\mathrm{PM}_{2.5}$ aerosol samples were collected on $37 \mathrm{~mm}$ polycarbonate filters (Nuclepore) using a Harvard impactor (Air Diagnostics, Harrison, ME, USA) with flow rate of $10 \mathrm{~L} \mathrm{~min}^{-1}$, at $2 \mathrm{~m}$ from the ground. ${ }^{28}$ The pilot study was located at the National Institute of Meteorology (INMET) station in Curitiba city, Paraná State, Brazil, (coordinates 2526'93'’ $\mathrm{S}, 49^{\circ} 13^{\prime} 85^{\prime \prime} \mathrm{O}$ ). The sampling site is a residential area near the city center, adjacent to two important highways with a significant flow of light and heavy duty vehicles.

To mimic the solubilization process of aerosol in the human lung, $\mathrm{PM}_{2.5}$ collected on filters were subjected to an in-vitro test. ${ }^{18}$ To this end, to each entire collected filter $6.00 \mathrm{~mL}$ of ALF was added. The samples were then incubated at $37^{\circ} \mathrm{C}$ and agitated at 40 cycles per minute for 1 hour and filtered using polyvinylidene difluoride (PVDF) membrane filters $(0.22 \mu \mathrm{m}$ pore size, Vertipure) to separate the supernatant (bioaccessible fraction) from the insoluble fraction. The supernatant was directly analyzed by GFAAS. A method blank was prepared in the same manner.

Concentrations are reported as $\mu \mathrm{g} \mathrm{m}^{-3}$ to enable comparison with air pollution guideline values.

\section{Results and Discussion}

\section{Instrumental Conditions study for the $\mathrm{Cu}, \mathrm{Cr}, \mathrm{Mn}$ and $\mathrm{Pb}$ in an $\mathrm{ALF}$ matrix}

To optimize the pyrolysis and atomization temperatures, the ALF was spiked with $25 \mu \mathrm{g} \mathrm{L} \mathrm{L}^{-1}$ $\mathrm{Cu}$ in the presence of a suitable chemical modifier. In general, a univariate study is performed in order to achieve the optimal pyrolysis temperature $\left(\mathrm{T}_{\mathrm{pyr}}\right)$ and atomization temperature $\left(\mathrm{T}_{\text {atom }}\right)$.

In Fig. 1, the pyrolysis curve shows that above $1200{ }^{\circ} \mathrm{C}$ the absorbance signal decreased indicating a $\mathrm{Cu}$ loss, possibly due to its volatilization. Therefore, the optimal $\mathrm{T}_{\text {pyr }}$ of $1100{ }^{\circ} \mathrm{C}$ was chosen taking into account the suitable thermal conditions providing the elimination of most of the 
matrix interferences to a fixed $\mathrm{T}_{\text {atom }}$ of $2300^{\circ} \mathrm{C}$. Then, the optimal $\mathrm{T}_{\mathrm{pyr}}\left(1100{ }^{\circ} \mathrm{C}\right)$ was maintained to investigate the influence of varying $\mathrm{T}_{\text {atom }}$ (range from $1900^{\circ} \mathrm{C}$ to $2400{ }^{\circ} \mathrm{C}$ ). As can be observed in Fig. 1, the $\mathrm{T}_{\text {atom }}$ of $2100{ }^{\circ} \mathrm{C}$ can be considered suitable, taking into account the satisfactory sensitivity (indicated by signal-to-background-ratio (SBR)) as observed by the $\mathrm{Cu}$ signal. In all experiments, the ratio of $\mathrm{Cu}$ absorbance signal from ALF matrix and the $\mathrm{Cu}$ absorbance in $1 \%\left(\mathrm{v} \mathrm{v}^{-1}\right) \mathrm{HNO}_{3}$ (reference solution), both at the same concentration level, was evaluated in order to verify the optimal thermal analysis conditions. In all experiments the chemical modifier solution containing $5 \mu \mathrm{g} \mathrm{Pd}: 0.5 \mu \mathrm{g} \mathrm{Mg}$ was employed. The range of the recovery values obtained for $\mathrm{Cu}$ $87-101 \%$.

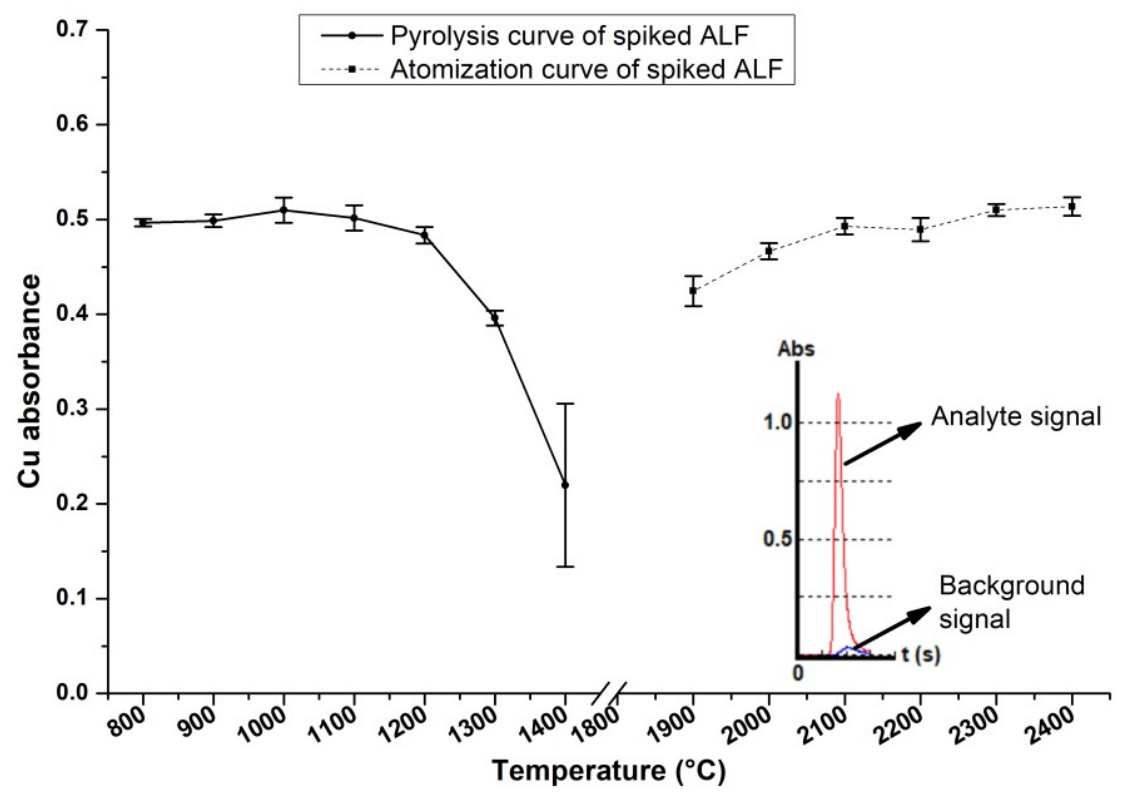

Figure 1. Pyrolysis and atomization temperatures optimized for ALF samples spiked with $25 \mu \mathrm{g} \mathrm{L}{ }^{-1}$ copper. Sample volume: $20 \mu \mathrm{L}$, chemical modifier: $5 \mu \mathrm{L}$. The optimization experiments were performed in triplicate, $\mathrm{n}=3$.

Chromium analyses with AAS methods are notoriously difficult due to the refractory nature of $\mathrm{Cr}$ which requires high atomization temperatures. In addition, $\mathrm{Cr}$ determination is highly wavelength dependent. For that reason the method was optimized by systematically studying the variation in the ratio of chromium absorbance signal of the ALF and $1 \%\left(\mathrm{v} \mathrm{v}^{-1}\right) \mathrm{HNO}_{3}$ solutions 
spiked with $25 \mu \mathrm{g} \mathrm{L}^{-1} \mathrm{Cr}$ with variation in wavelength. The optimized wavelength was found to be $360.5 \mathrm{~nm}$, using $2 \mu \mathrm{g}$ of magnesium as chemical modifier.

The optimal $\mathrm{T}_{\text {pyr }}$ of $1550{ }^{\circ} \mathrm{C}$ was chosen (Fig. 2) because it produced the lowest SBR and the best recovery values for the $\mathrm{Cr}$ in different media. The atomization temperature of $2400{ }^{\circ} \mathrm{C}$ produced the highest absorbance signal for chromium in ALF matrix. Using these optimal conditions recovery values of $93 \%$ were obtained which can be considered acceptable quantification in the presence of the matrix interferences. ${ }^{29-31}$

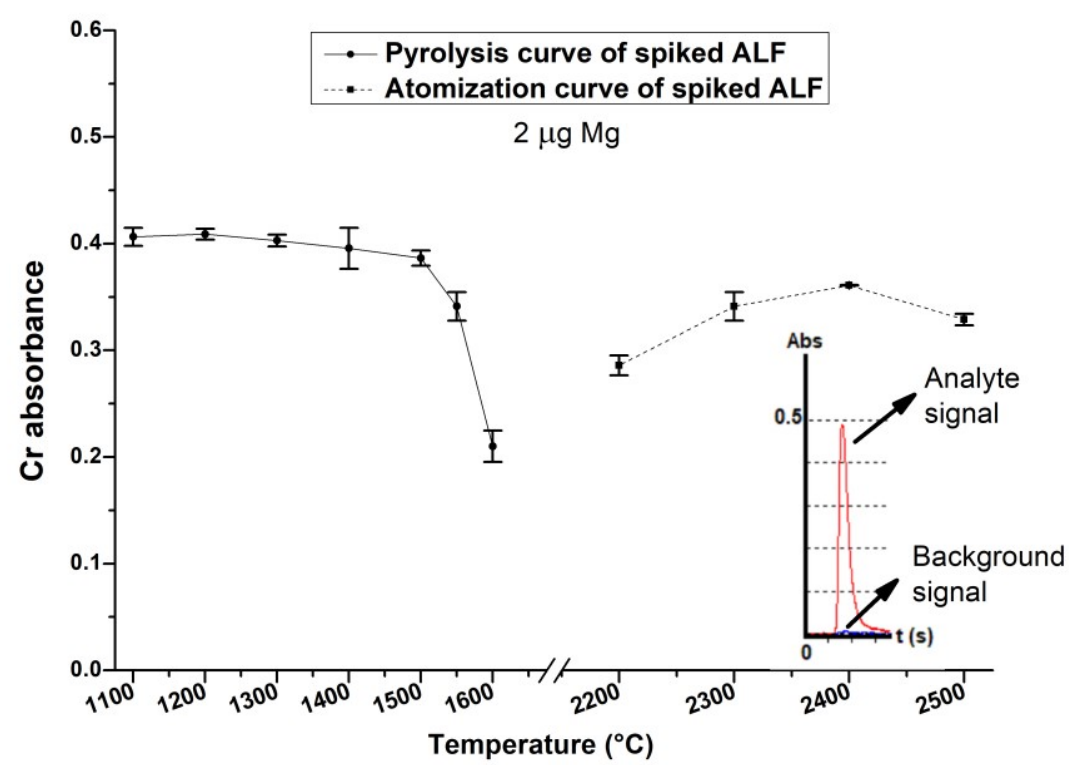

Figure 2. Pyrolysis and atomization temperatures optimization for ALF samples spiked with $25 \mu \mathrm{g} \mathrm{L}-1$

chromium. Sample volume: $20 \mu \mathrm{L}$, chemical modifier: $5 \mu \mathrm{L}$. The optimization experiments were performed in triplicate, $\mathrm{n}=3$.

For the Mn quantification $2 \mu \mathrm{g} \mathrm{Mg}$ was used as chemical modifier. For the fixed $\mathrm{T}_{\text {atom }}$ of $2200{ }^{\circ} \mathrm{C}$, an optimal $\mathrm{T}_{\text {pyr }}$ of $1200{ }^{\circ} \mathrm{C}$ was chosen as can be observed in Fig. 3. The Mn recovery values were $88-105 \%$. The $\mathrm{T}_{\text {atom }}$ previously defined $\left(\mathrm{Ta}=2200{ }^{\circ} \mathrm{C}\right)$ providing suitable conditions for the Mn quantification without further optimization. This is most likely due to a $\mathrm{T}_{\text {pyr }}$ promoting suitable reaction conditions that improved the volatility. 


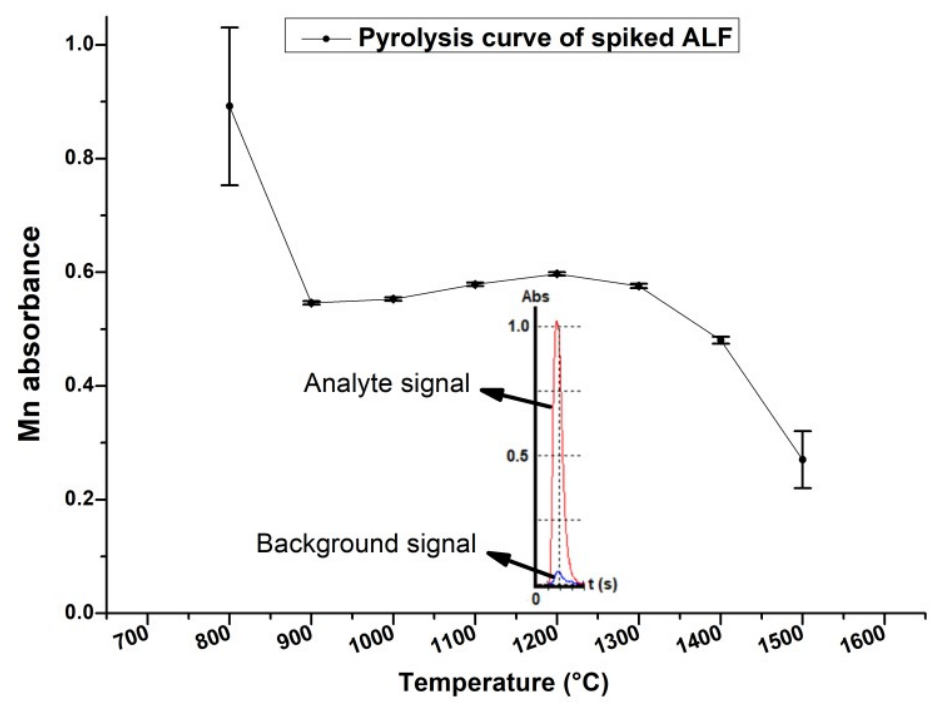

Figure 3. Pyrolysis temperature optimization at $\mathrm{T}_{\text {atom }}$ fixed at $2200^{\circ} \mathrm{C}$ for ALF samples spiked with $25 \mu \mathrm{g} \mathrm{L} \mathrm{L}^{-1}$ manganese. Sample volume: $20 \mu \mathrm{L}$, chemical modifier: $5 \mu \mathrm{L}$. The optimization experiments were performed in triplicate, $n=3$.

For the $\mathrm{Pb}$ quantification, the matrix interferences on the $\mathrm{Pb}$ signal could only be solved employing the factorial design as the Central Composite Design (CCD). The pyrolysis and atomization temperatures in GFAAS are generally optimized using univariate methods (one-at-atime variation in parameter) in which case the interaction effects between the studied variables are not generally evaluated. ${ }^{32}$ The use of the factorial design is based a multivariate optimization strategy that allows the identification of the factor, as well as the possible interactions that may affect the result of an experiment. In this study, the response variable (recovery values) was measured for all possible combinations of the chosen pyrolysis and atomization temperature levels. For the $\mathrm{Pb}$ quantification, the pyrolysis and atomization temperatures were evaluated by Central Composite Design (CCD), which presents 5 levels $(-2,-1,0,+1$ and 2 square root), as presented in Table S2. This approach allowed successful optimization of $\mathrm{Pb}$ determination in this matrix, which could not be achieved using the univariate approach followed for $\mathrm{Cu}, \mathrm{Cr}$, and $\mathrm{Mn}$.

The recovery was also evaluated by ratio from absorbance signal between $\mathrm{Pb}$ spiked ALF and $\mathrm{Pb}$ standard solutions (reference solution) both at the same concentration level, $50 \mu \mathrm{g} \mathrm{L}-1 \mathrm{~Pb}$. In these experiments a chemical modifier containing $5 \mu \mathrm{g}$ Pd: $3 \mu \mathrm{g} \mathrm{Mg}$ was used. The Fig. 4 shows the 
profile of the response surface under each instrumental condition evaluated. These experiments were performed randomly, and the statistical procedures were done using Statistica 7.0 software (StarSoft, Tulsa, USA).

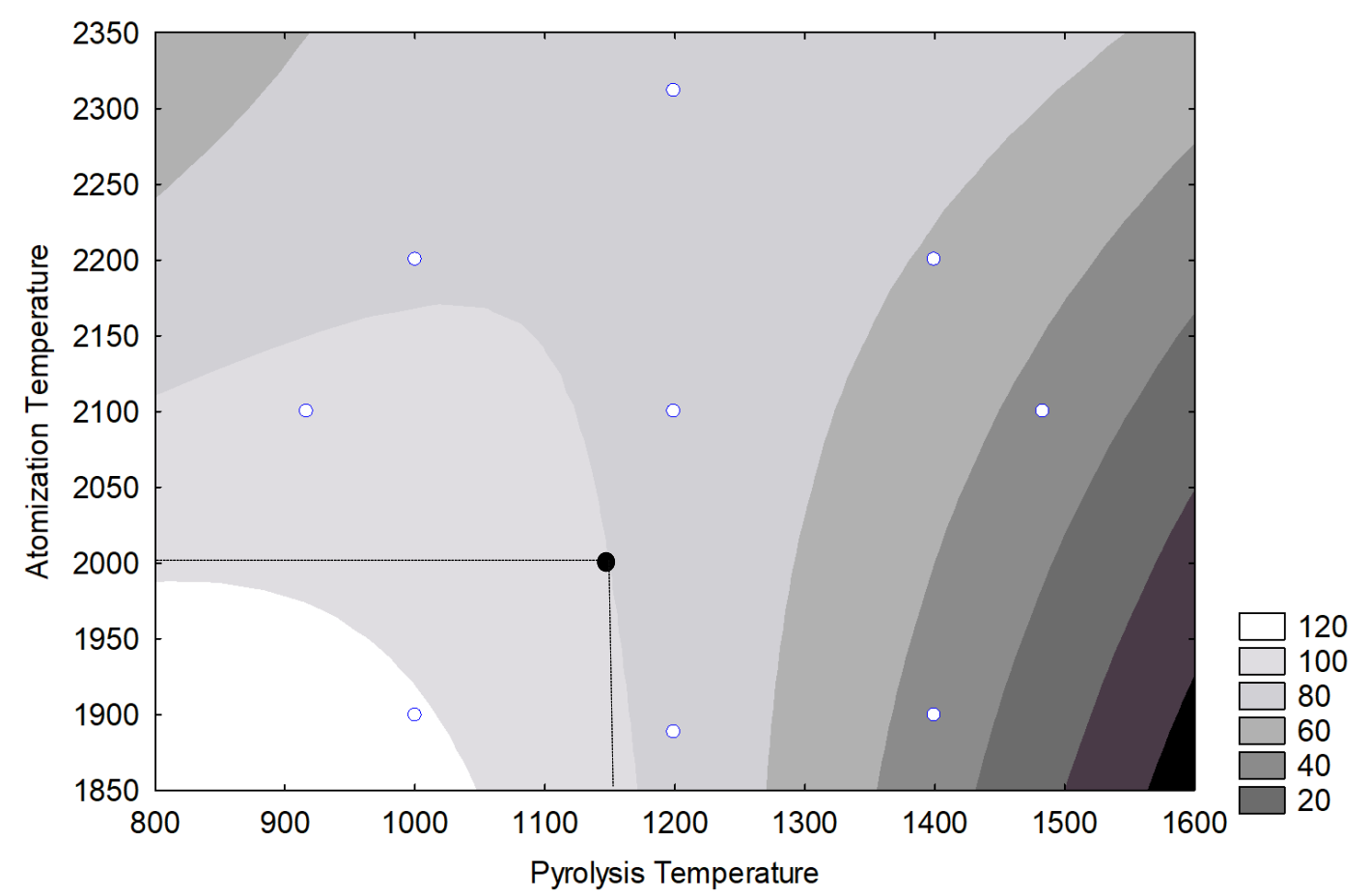

Figure 4. Contour diagram obtained for the ratio of absorbance values between $\mathrm{Pb}$ spiked ALF samples and $\mathrm{Pb}$ standard solution, both containing $50 \mu \mathrm{g} \mathrm{L}^{-1} \mathrm{~Pb}$ in the presence of chemical modifier $(5 \mu \mathrm{g} \mathrm{Pd}+3 \mu \mathrm{g} \mathrm{Mg})$. Sample volume: $20 \mu \mathrm{L}$, chemical modifier: $5 \mu \mathrm{L}$. The optimization experiments were performed in duplicate, $n=2$.

In this study, the recovery value (response variable) depends on the possible interactions between the response variable as well as the levels of two variables $\left(\mathrm{T}_{\mathrm{pyr}}\right.$ and $\left.\mathrm{T}_{\text {atom }}\right)$ studied by the CCD design that can be represented by a contour diagram Fig. 4.

Satisfactory recovery values (80-100\%) for $\mathrm{Pb}$ in ALF were obtained applying a $\mathrm{T}_{\text {pyr }}$ of 1150 ${ }^{\circ} \mathrm{C}$ and a $\mathrm{T}_{\text {atom }}$ of $2000{ }^{\circ} \mathrm{C}$, as indicated in Fig.4. The recovery value on each contour was constant, and the target optimum instrumental condition is indicated. The accuracy of the developed methods was evaluated by addition-recovery experiments in the ALF, in agreement with the aqueous calibration curve (Table II). 
Table II. Addition-recovery values obtained for $\mathrm{Cu}, \mathrm{Cr}, \mathrm{Mn}$ and $\mathrm{Pb}$ in ALF by GFAAS (mean value $\pm \mathrm{sd}, \mathrm{n}=3)$.

\begin{tabular}{|c|c|c|c|}
\hline & $\begin{array}{c}\text { Concentration } \\
\text { level added } \\
\left(\mu \mathrm{g} \mathrm{L}^{-1}\right)^{*}\end{array}$ & $\begin{array}{c}\text { Found } \\
\text { Value }\left(\mu \mathrm{g} \mathrm{L}^{-1}\right)\end{array}$ & Recovery (\%) \\
\hline \multirow{6}{*}{$\mathbf{C u}$} & 2 & $2 \pm 0.1$ & 100 \\
\hline & 10 & $11 \pm 0.1$ & 110 \\
\hline & 20 & $18 \pm 1$ & 90 \\
\hline & 30 & $27 \pm 0.4$ & 90 \\
\hline & 50 & $52 \pm 0.3$ & 104 \\
\hline & 80 & $78 \pm 3$ & 97 \\
\hline \multirow{3}{*}{$\mathbf{C r}$} & 4 & $5 \pm 0.3$ & 125 \\
\hline & 10 & $11 \pm 0.4$ & 110 \\
\hline & 25 & $25 \pm 1$ & 100 \\
\hline \multirow{3}{*}{ Mn } & 2 & $2 \pm 0.2$ & 100 \\
\hline & 10 & $10 \pm 0.1$ & 100 \\
\hline & 15 & $15 \pm 0.1$ & 100 \\
\hline \multirow{7}{*}{$\mathbf{P b}$} & 25 & $23 \pm 0.2$ & 93 \\
\hline & 35 & $34 \pm 0.5$ & 98 \\
\hline & 10 & $8 \pm 0.1$ & 80 \\
\hline & 20 & $22 \pm 0.1$ & 110 \\
\hline & 50 & $49 \pm 0.5$ & 98 \\
\hline & 70 & $68 \pm 0.3$ & 97 \\
\hline & 100 & $93 \pm 2$ & 93 \\
\hline
\end{tabular}

* different amounts of the standard solution were added into the fix sample volume $(5 \mathrm{~mL})$ of ALF for each concentration level evaluated.

Satisfactory recovery values were obtained and different calibration curves for $\mathrm{Cu}, \mathrm{Mn}$ and $\mathrm{Pb}$ were used due to varying in the concentration levels of the PM2.5 samples collected in the city of Curitiba. ${ }^{16}$ The analytical performance parameters of the method were evaluated, as required (Table $\mathrm{S} 3)^{33}$

The ALF samples containing $\mathrm{Cu}, \mathrm{Cr}, \mathrm{Mn}$ and $\mathrm{Pb}$ were analyzed by GFAAS and the results are shown in Table III. 
Table III. Soluble concentration $\left(\mu \mathrm{g} \mathrm{L}{ }^{-1}\right)$ in ALF and atmospheric soluble concentration $\left(\mathrm{ng} \mathrm{m}^{-3}\right)$ in $\mathrm{PM}_{2.5}$ for $\mathrm{Cu}, \mathrm{Cr}, \mathrm{Mn}$ and $\mathrm{Pb}$ in the $\mathrm{ALF}$ by GFAAS, (mean value $\pm \mathrm{sd}, \mathrm{n}=3$ ).

\begin{tabular}{|c|c|c|c|c|c|c|c|c|c|}
\hline \multirow[b]{2}{*}{ Sample } & \multirow{2}{*}{$\begin{array}{c}\begin{array}{c}\text { Air } \\
\text { Volume }\end{array} \\
\left(\mathrm{m}^{3}\right)\end{array}$} & \multicolumn{4}{|c|}{ Soluble Concentration in ALF $\left(\mu \mathrm{g} \mathrm{L}^{-1}\right)$} & \multicolumn{4}{|c|}{ Atmospheric soluble concentration $\left(\mathrm{ng} \mathrm{m}^{-3}\right)$} \\
\hline & & $\mathbf{C u}$ & $\mathrm{Cr}$ & Mn & $\mathbf{P b}$ & $\mathbf{C u}$ & $\mathrm{Cr}$ & Mn & $\mathbf{P b}$ \\
\hline 1 & 216 & $35 \pm 0.01$ & $5.1 \pm 0.41$ & $17 \pm 2$ & $71 \pm 1$ & $0.96 \pm 0.0002$ & $0.14 \pm 0.01$ & $0.47 \pm 0.04$ & $1.9 \pm 0.04$ \\
\hline 2 & 103 & $20 \pm 0.1$ & & $13 \pm 0.1$ & $144 \pm 1$ & $1.1 \pm 0.01$ & 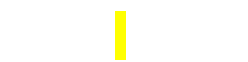 & $0.75 \pm 0.01$ & $8.4 \pm 0.08$ \\
\hline 3 & 99 & $16 \pm 0.4$ & $5.0 \pm 0.01$ & $8.3 \pm 0.20$ & $66 \pm 1$ & $0.98 \pm 0.02$ & $0.30 \pm 0.001$ & $0.50 \pm 0.01$ & $4.0 \pm 0.08$ \\
\hline 4 & 100 & $20 \pm 0.04$ & & $11 \pm 0.1$ & $124 \pm 0.4$ & $1.2 \pm 0.003$ & 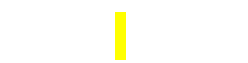 & $0.64 \pm 0.01$ & $7.4 \pm 0.02$ \\
\hline 5 & 102 & $26 \pm 0.4$ & & $12 \pm 0.04$ & $24 \pm 0.5$ & $1.6 \pm 0.02$ & 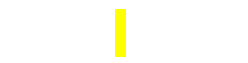 & $0.68 \pm 0.003$ & $1.4 \pm 0.03$ \\
\hline 6 & 99 & $14 \pm 0.2$ & $4.1 \pm 0.11$ & $10 \pm 0.03$ & $24 \pm 0.1$ & $0.86 \pm 0.01$ & $0.25 \pm 0.01$ & $0.59 \pm 0.002$ & $1.5 \pm 0.01$ \\
\hline 7 & 100 & $39 \pm 0.6$ & $12 \pm 0.3$ & $13 \pm 0.2$ & $136 \pm 1$ & $2.4 \pm 0.03$ & $0.71 \pm 0.02$ & $0.79 \pm 0.01$ & $8.2 \pm 0.07$ \\
\hline 8 & 115 & $16 \pm 0.02$ & $7.4 \pm 0.72$ & $11 \pm 0.07$ & $113 \pm 3$ & $0.83 \pm 0.001$ & $0.39 \pm 0.04$ & $0.57 \pm 0.004$ & $5.9 \pm 0.17$ \\
\hline Average & & & & & & $1.2 \pm 0.01$ & $0.41 \pm 0.01$ & $0.62 \pm 0.01$ & $4.8 \pm 0.03$ \\
\hline
\end{tabular}


The results of the soluble concentration of each chemical element investigated in the ALF were calculated as atmospheric concentration (Table III). The mean atmospheric soluble concentrations of the analytes in the samples were $1.2 \pm 0.01 \mathrm{ng} \mathrm{m}^{-3} \mathrm{Cu}, 0.41 \pm 0.01 \mathrm{ng} \mathrm{m}^{-3} \mathrm{Cr}, 0.62$ $\pm 0.01 \mathrm{ng} \mathrm{m}^{-3} \mathrm{Mn}$, and $4.8 \pm 0.03 \mathrm{ng} \mathrm{m}^{-3} \mathrm{~Pb}$.

Considering the historical elemental average of $\mathrm{PM}_{2.5}$ in Curitiba as being $\mathrm{Cu} 3.3 \mathrm{ng} \mathrm{m}^{-3}, \mathrm{Cr}$ $2.1 \mathrm{ng} \mathrm{m}^{-3}, \mathrm{Mn} 6.1 \mathrm{ng} \mathrm{m}^{-3}$, and $\mathrm{Pb} 21 \mathrm{ng} \mathrm{m}^{-3},{ }^{16}$ the bioaccessibility percentage of the analyzed samples were calculated to be $\mathrm{Cu} 38 \%$; $\mathrm{Cr} 20 \%$; $\mathrm{Mn} \mathrm{10 \%}$; and $\mathrm{Pb} 23 \%$ (where bioaccessibility is defined as the ratio between the mass leached onto ALF and the total mass).

While the evidence for differential solubility of particulate matter is far from conclusive, Wiseman and Zereini ${ }^{20}$ evaluated the soluble fraction of some chemical elements in ALF simulated lung fluid using a similar in vitro procedure bar a difference in incubation time ( 24 hours in comparison to 1 hour in this investigation). They found that the soluble inorganic content of the samples was: $42.4 \mathrm{ng} \mathrm{m}^{-3} \mathrm{Cu}, 3.0 \mathrm{ng} \mathrm{m}^{-3} \mathrm{Cr}, 9.9 \mathrm{ng} \mathrm{m}^{-3} \mathrm{Mn}$ and $10.9 \mathrm{ng} \mathrm{m}^{-3} \mathrm{~Pb}$, indicating higher solubility level of $\mathrm{PM}_{2.5}$ in comparison with the city of Curitiba, Brazil. However, considering the difference in incubation period, the results for $\mathrm{Cr}, \mathrm{Mn}$ and $\mathrm{Pb}$ seem to be reasonably close to each other.

The values indicated obtained for the $\mathrm{Cu}, \mathrm{Cr}$ and $\mathrm{Mn}$ in the atmospheric soluble fraction were lower than the inhalation risk concentrations as reported: $\mathrm{Cu} 100 \mu \mathrm{g} \mathrm{m}{ }^{-3},{ }^{11} \mathrm{Cr} 8 \mathrm{ng} \mathrm{m}^{-3},{ }^{12}$ and $\mathrm{Mn} 50$ ng $\mathrm{m}^{-3} .{ }^{13}$ However, for $\mathrm{Pb}$, the atmospheric soluble fraction of all samples analyzed exceeded the inhalation risk unit of $0.012 \mathrm{ng} \mathrm{m}^{-3} .{ }^{14}$ The chemical health risk assessment analysis of $\mathrm{Pb}$ exposure was performed with the average soluble concentration of $\mathrm{Pb}$ in ALF and the inhalation risk unit based on the previously methods developed by the United States Environmental Protection Agency using the Risk Assessment Information System. ${ }^{34}$ This method modeled the carcinogenic risks that may occur due to $\mathrm{Pb}$ exposure through inhalation of the $\mathrm{PM}_{2.5}$ The results indicate the probability of 2 residents develop carcinogenic diseases over a lifetime in each group of 100 million inhabitants. 
Currently, $\mathrm{Pb}$ is not an additive used in Brazilian gasoline, but it can be found as a trace contaminant in diesel generating significant emissions of $\mathrm{Pb}$ to the atmosphere by combustion of these fuels, e.g., old trucks, locomotives, and thermal power plants. ${ }^{21}$ The values reported here stresses that it is plausible to assume that long-term low-dose exposure will have a severe effect on public health in the city.

\section{Conclusions}

We have shown that GFAAS with Deuterium lamp correction capability can be used to quantify $\mathrm{Cu}, \mathrm{Cr}, \mathrm{Mn}$, and $\mathrm{Pb}$ in a matrix with high salt concentration. The developed method provided suitable sensitivity and accuracy despite the absence of Zeeman correction capability. Furthermore, minimal sample preparation was required and pre-treatment was limited to relative simple chemical modifiers that is inexpensive. The optimized conditions was used to determine the concentration of $\mathrm{Cu}, \mathrm{Cr}, \mathrm{Mn}$, and $\mathrm{Pb}$ from leachates produced after $\mathrm{PM}_{2.5}$ samples were incubated at $37^{\circ} \mathrm{C}$ in an ALF with high ionic strength. Results showed comparable values to those published in literature. This robust and straightforward GFAAS method is pivotal for low and middle-income countries were most air pollution adverse effects occur, and more sophisticated technologies are not always available.

\section{Declaration of Conflicting Interests}

The authors declared no potential conflicts of interest with respect to the research, authorship, and/or publication of this article.

\section{Acknowledgment}

Financial support of Coordination for the Improvement of Higher Education Personnel (CAPES), the National Council for Scientific and Technological Development (CNPq), and the 
Araucaria Foundation for Scientific and Technological Development of Parana (Grant no. 435/2014)

\section{ORCID ID}

Andrea Oliveira (https://orcid.org/0000-0003-4381-9908)

\section{Supplemental Material}

The supplemental material mentioned in the text, consisting of the important parameters that support the data obtained in this work and it is available in the online version of the journal.

\section{References}

1. C.A. Pope, M. Ezzati, D.W. Dockery. "Fine-Particulate Air Pollution and Life Expectancy in the United States”. N. Engl. J. Med. 2009. 360: 376-386.

2. C. Canova, C. Dunster, F.J. Kelly, C. Minelli, P.L. Shah, C. Caneja, M.K. Tumilty, P. Burney. "PM10-Induced Hospital Admissions for Asthma and Chronic Obstructive Pulmonary Disease the Modifying Effect of Individual Characteristics”. Epidemiol. 2012. 23: 607-615.

3. C. Angelé-Martínez, C. Goodman, J. Brumaghim. "Metal-Mediated DNA Damage and Cell Death: Mechanisms, Detection Methods, and Cellular Consequences”. Metallomics. 2014. 6(8): 1358-1381.

4. S. Becker, A.D. Lisa, M.S. Joleen, C.G. teven, B.D. Robert, T.H. Yuh-Chin. "Seasonal Variations in Air Pollution Particle-Induced Inflammatory Mediator Release and Oxidative Stress". Environ. Health Persp. 2005. 113(8): 1032-1038.

5. P. Chen, S. Chakraborty, S. Mukhopadhyay, E. Lee, M.M.B. Paoliello, A.B. Bowman, M. Aschner. "Manganese Homeostasis in the Nervous System". J. Neurochem. 2015. 134(4): 601-610. 
6. G.C. Fang, Y.C. Chen, C.T. Lo, M.H. Cho, Y.J. Zhuang, K.H. Tsai, C.Y. Huang, Y.F. Xiao. "Concentrations and Analysis of Health Risks of Ambient Air Metallic Elements at Longjing Site in Central Taiwan”. Environ. Geochem. Health. 2018. 40(1): 461-472.

7. R.H.M. Godoi, G. Polezer, G.C. Borillo, A. Brown, F.B. Valebona, T.O.B. Silva, A.B. Ingberman, M. Nalin, C.I. Yamamoto, S. Potgieter-Vermaak, R.A. Penteado Neto, M.R. de Marchi, P.H. Saldiva, T. Pauliqueves, A.F. Godoi "Influence on the Oxidative Potential of a Heavy-Duty Engine Particle Emission due to Selective Catalytic Reduction System and Biodiesel Blend". Sci. Total Environ. 2016. 560: 179-185.

8. P.B. Kurt-Karakus. "Determination of Heavy Metals in Indoor Dust from Istanbul, Turkey: Estimation of the Health Risk”. Environ. Int. 2012. 50: 47-55.

9. J.A. Fisher, R.C. Puett, F. Laden, G.A. Wellenius, A. Sapkota, D. Liao, et al. "Case-crossover analysis of short-term particulate matter exposures and stroke in the health professionals follow-up study”. Environ Int. 2019. 124: 153-160.

10. C.I. Davidson, R.F. Phalen, P.A. Solomon. "Airborne Particulate Matter and Human Health: A Review". Aerosol Sci. Technol. 2005. 39: 737-749.

11. US EPA, Hazardous Air Pollutants, Health Effects Notebook for Hazardous Air Pollutants, 2017. Available: http//www.epa.gov.br[accessed Nov 12 2019]

12. IRIS. Integrated Risk Information System. U.S. Environmental Protection Agency Chemical Assessment Summary, Chromium (VI) (CASRN 18540-29-9), 2003. Available: https://cfpub.epa.gov [accessed Oct 21 2019] 
13. IRIS. Integrated Risk Information System. U.S. Environmental Protection Agency Chemical Assessment Summary, Manganese, (CASRN 7439-96-5) 2002. Available: https://cfpub.epa.gov [accessed Oct 212019$]$

14. Cal/EPA. The California Environmental Protection Agency. Toxic Air Contaminant List with Staff Reports/Executive Summaries, Inorganic Lead TAC - Full Document, 1997.

15. S. Potgieter-Vermaak, G. Rotondo, V. Novakovic, S. Rollins, R. Van Grieken. "ComponentSpecific Toxic Concerns of the Inhalable Fraction of Urban Road Dust”. Environ. Geochem. Health 2012. 34: 689-696.

16. G. Polezer, Y.S. Tadano, H.V. Siqueira, A.F.L. Godoi, C.I. Yamamoto, P.A. de André, T. Pauliquevis, M.F. Andrade, A. Oliveira, P.H.N. Saldiva, P.E. Taylor, R.H.M. Godoi. "Assessing the Impact of PM2.5 on Respiratory Disease using Artificial Neural Networks”. Environ. Pollut. 2018. 235: 394-403.

17. N.B. Ivanenko, A.A. Ganeev, N.D. Solovyev, L.N. Moskvin. "Determination of Trace Elements in Biological Fluids". J. Anal. Chem. 2011. 66: 784-799.

18. C. Colombo, A.J. Monhemius, J.A. Plant. "Platinum, Palladium and Rhodium Release from Vehicle Exhaust Catalysts and Road Dust Exposed to Simulated Lung Fluids". Ecotoxicol. Environ. Saf. 2008. 71(3): 722-730.

19. C. Julien, P. Esperanza, M. Bruno, L.Y. Alleman. "Development of an in Vitro Method to Estimate Lung Bioaccessibility of Metals from Atmospheric Particles”. J. Environ. Monitor. 2011. 13(3): 621-630. 
20. C.L.S. Wiseman, F. Zereini. "Characterizing Metal(loid) Solubility in Airborne PM10, PM2.5 and PM1 in Frankfurt, Germany Using Simulated Lung Fluids". Atmos. Environ. 2014. 89: 282289.

21. S.W. Li, H.B. Li, J. Luo, H.M. Li, X., Qian X, M.M. Liu, J. Bi, X.Y. Cui, L.Q. Ma. "Influence of Pollution Control on Lead Inhalation Bioaccessibility in PM2.5: A Case Study of 2014 Youth Olympic Games in Nanjing”. Environ. Int. 2016. 94: 69-75

22. P. Coufalík, P. Mikuska, T. Matousek, Z. Vecera. "Determination of the Bioaccessible Fraction of Metals in Urban Aerosol using Simulated Lung Fluids”. Atmos. Environ. 2016. 140: 469-475.

23. W.E. Hillwalker, K.A. Anderson. "Bioacessibility of Metals in Alloys: Evaluation of Three Surrogate Biofluids”. Environ. Pollut. 2014. 185: 52-58.

24. A. Mukhtar, V. Mohr, A. Limbeck. "The Suitability of Extraction Solutions to Assess Bioaccessible Trace Metal Fractions in Airborne Particulate Matter: A Comparison of Common Leaching Agents”. Environ. Sci. Pollut. Res. Int. 2015. 22(21): 16620-16630.

25. Z-J. Tang, X. Hu, J.-Q. Qiao, H.-Z. Lian. “Size Distribution, Bioaccessibility and Health Risks of Indoor/Outdoor Airborne Toxic Elements Collected from School Office Room”. Atmosphere. 2018. 9(9): 340-353.

26. W. Stopford, J. Turner, D. Cappellini, T. Brock. "Bioaccessibility Testing of Cobalt Compounds". J. Environ. Monit. 2003. 5(4): 675-680.

27. K. Midander, J. Pan, I.O. Wallinder, C. Leygraf. "Metal Release from Stainless Steel Particles in Vitro-Influence of Particle Size”. J. Environ. Monit. 2007. 9(1): 74-81.

28. V.A. Marple, K.L. Rubow, W. Turner, J.D. Spengler. “Low Flow Rate Sharp Cut Impactors for Indoor Air Sampling: Design and Calibration” JAPCA. 1987. 37: 1303-1307. 
29. C.E.R. Paula, G.F.B. Cruz, C.M.S.P. Rezende, R.J. Cassella. "Determination of Cr and Mn in Moisturizing Creams by Graphite Furnace Atomic Absorption Spectrometry through Direct Introduction of the Samples in the Form of Emulsions". Microchem. J. 2016. 127: 1-6.

30. R. Dobrowolski. "Determination of $\mathrm{Ni}$ and $\mathrm{Cr}$ in Soils by Slurry Graphite Furnace Atomic Absorption Spectrometry”. Spectrochim. Acta B 1996. 51(2): 221-227.

31. M. Wójciak-Kosior, W. Szwerc, M. Strzemski, Z. Wichłacz, J. Sawicki, R. Kocjan, M. Latalski, I. Sowaa. "Optimization of High-Resolution Continuum Source Graphite Furnace Atomic Absorption Sectrometry for Direct Analysis of Selected Trace Elements in Whole Blood Samples". Talanta. 2017. 165: 351-356.

32. J.N. Miller, J.C. Miller. "Statistics and Chemometrics for Analytical Chemistry". England: Pearson Education Ltda., 2005. Fifth ed.

33. European communities. Implementing Council Directive 96/23/EC concerning the performance of analytical methods and the interpretation of results. Official Journal of the European Communities, (OJEC) (2002) 3044.

34. R.H.M. Godoi, A.F.L. Godoi, L.C. de Quadros, G. Polezer, T.O.B. Silva, C.I. Yamamoto, R. van Grieken, S. Potgieter-Vermaak. "Risk Assessment and Spatial Chemical Variability of PM Collected at Selected Bus Stations”. Air Qual. Atmos. Health 2013 6: 725-735. 


\section{Figure Captions}

Figure 1. Pyrolysis and atomization temperatures optimized for ALF samples spiked with $25 \mu \mathrm{g} \mathrm{L}{ }^{-1}$ copper. Sample volume: $20 \mu \mathrm{L}$, chemical modifier: $5 \mu \mathrm{L}$. The optimization experiments were performed in triplicate, $\mathrm{n}=3$.

Figure 2. Pyrolysis and atomization temperatures optimization for ALF samples spiked with $25 \mu \mathrm{g}$ $\mathrm{L}^{-1}$ chromium. Sample volume: $20 \mu \mathrm{L}$, chemical modifier: $5 \mu \mathrm{L}$. The optimization experiments were performed in triplicate, $\mathrm{n}=3$.

Figure 3. Pyrolysis temperature optimization at $\mathrm{T}_{\text {atom }}$ fixed at $2200{ }^{\circ} \mathrm{C}$ for ALF samples spiked with $25 \mu \mathrm{g} \mathrm{L} \mathrm{L}^{-1}$ manganese. Sample volume: $20 \mu \mathrm{L}$, chemical modifier: $5 \mu \mathrm{L}$. The optimization experiments were performed in triplicate, $n=3$.

Figure 4. Contour diagram obtained for the ratio of absorbance values between $\mathrm{Pb}$ spiked ALF samples and $\mathrm{Pb}$ standard solution, both containing $50 \mu \mathrm{g} \mathrm{L}^{-1} \mathrm{~Pb}$ in the presence of chemical modifier $(5 \mu \mathrm{g} \mathrm{Pd}+3 \mu \mathrm{g} \mathrm{Mg})$. Sample volume: $20 \mu \mathrm{L}$, chemical modifier: $5 \mu \mathrm{L}$. The optimization experiments were performed in duplicate, $n=2$. 